\title{
COOPERATIVE DEVELOPMENT STRATEGY IN EFFORTS TO INCREASE COMPETITIVENESS IN KARAWANG REGENCY (CASE STUDY ON GROUP OF NON-EMPLOYEE COOPERATIVES IN KARAWANG REGENCY)
}

\author{
Siti Nurdinasari \\ Puji Isyanto \\ Singaperbangsa Karawang University, Buana Perjuangan Karawang University \\ email: sitinurdinasari@gmail.com, puji.isyanto@ ubpkarawang.ac.id
}

\begin{abstract}
The purpose of the research to find out how the implementation of nonemployee cooperative management strategy in Kabupaten Karawang. Research with qualitative approach based on postpositivesme philosophy, is used to examine the natural object condition where the researcher is as the key instrument, the sampling of the data source is done purposively, the collecting technique with triangulation, the data analysis is inductive / qualitative, and the result of more qualitative research Emphasizing the meaning of generalization.

From the results of research, obtained the following conclusions: (1). Non-Employee Cooperatives in Kabupaten Karawang that have been established Implementation Strategy management is still not optimal, (2). The concept of competitiveness of non-Employee Cooperatives in Kabupaten Karawang as an independent economic institution, has not been applied, (3). Constraints faced by cooperatives in facing the competitiveness of cooperatives implicate inhibiting the ability of the competitiveness of cooperatives in Karawang regency, especially Human Resources which is the main resources as a driver of cooperatives and strategic management of human centered cooperatives, (4). Cooperative development strategies in an effort to increase competitiveness require development and require the attention of various parties. Furthermore, the established cooperatives should apply strategic management by applying the organization's and management's standards seen from the organization.
\end{abstract}

Keywords: Cooperative, Strategic Management, Competitiveness.

\section{Latar Belakang Masalah}

Undang-Undang Nomor 17 Tahun 2012 tentang perkoperasian bahwa Pembangunan perekonomian nasional bertujuan untuk mewujudkan kedaulatan politik dan ekonomi Indonesia melalui pengelolaan sumber daya ekonomi dalam suatu iklim pengembangan dan perberdayaan Koperasi yang memiliki peran strategis dalam tata ekonomi nasional berdasarkan asas kekeluargaan dan demokrasi ekonomi. Semangat ekonomi rakyat dan sistem ekonomi rakyat sudah ada sejak proklamasi kemerdekaan. Pengalaman di tanah air kita lebih unik karena koperasi yang pernah lahir dan telah tumbuh secara alami di jaman penjajahan, kemudian setelah kemerdekaan diperbaharui dan diberikan kedudukan yang sangat tinggi dalam penjelasan Undang Undang Dasar 1945. Dan atas dasar itulah kemudian melahirkan berbagai penafsiran bagaimana harus mengembangkan koperasi (Soetrisno, 2003). 
Koperasi yang sering disebut sebagai sokoguru ekonomi kerakyatan ini, batasannya dirumuskan dalam Undang-Undang Nomor 17 tahun 2012 tentang Perkoperasian Bab 1 Pasal 1ayat (1) sebagai berikut: Koperasi adalah badan Hukum yang didirikan oleh orang perseorangan atau badan hukum Koperasi, dengan pemisahan kekayaan para anggotanya sebagai modal untuk menjalankan usaha, yang memenuhi aspirasi dan kebutuhan bersama di bidang ekonomi, sosial, dan budaya sesuai dengan nilai dan prinsip koperasi. Jika koperasi dipandang dari sudut ekonomi, pengertian koperasi dapat dinyatakan dalam kriteria identitas yaitu anggota sebagai pemilik dan sekaligus pelanggan. Ropke (2005 : 24) koperasi adalah suatu organisasi bisnis yang para pemiliknya/anggotanya adalah juga pelanggan utama perusahaan tersebut. Kriteria identitas suatu koperasi akan merupakan dalil/prinsip identitas yang membedakan unit usaha koperasi dari unit usaha yang lainnya.

Lembaga koperasi yang sejak awal diperkenalkan memang sudah diarahkan untuk berpihak kepada kepentingan ekonomi rakyat yang dikenal sebagai golongan ekonomi lemah. Strata ini biasanya berasal dari kelompok masyarakat kelas menengah kebawah. Eksistensi koperasi memang merupakan suatu fenomena tersendiri, sebab tidak satu lembaga sejenis lainnya yang mampu menyamainya, tetapi sekaligus diharapkan menjadi penyeimbang terhadap pilar ekonomi lainnya. Lembaga koperasi oleh banyak kalangan, diyakini sangat sesuai dengan budaya dan tata kehidupan bangsa Indonesia. Di dalamnya terkandung muatan menolong diri sendiri, kerjasama untuk kepentingan bersama (gotong royong), dan beberapa esensi moral lainnya. Sangat banyak orang mengetahui tentang koperasi meski belum tentu sama pemahamannya, apalagi juga hanya sebagian kecil dari populasi bangsa ini yang mampu berkoperasi secara benar dan konsisten. Koperasi Indonesia masih identik dengan usaha skala kecil, usaha sampingan, dan dijalankan masyarakat miskin. Sebagai badan usaha berbadan hukum dan melakukan kegiatan berdasarkan prinsip ekonomi, sesungguhnya koperasi adalah suatu kegiatan usaha karena prinsip ekonomi itu sendiri merupakan filosofi yang tidak dapat dilepaskan dari tujuan mencari keuntungan.

Koperasi di berbagai negara justru tumbuh dan berkembang pesat, peran koperasi sebagai tulang punggung perekonomian nasional masih jauh dari perhatian. Pembangunan koperasi sampai saat ini lebih bertumpu pada peran pemerintah yang menjadikan gerakan koperasi sebagai sub system perekonomian nasional, sehingga koperasi ditumbuhkan dengan berbagai cara pendekatan offisialiasasi. Istilah koperasi dikenal luas, tapi perkembangannya banyak yang tidak sehat. Disisi lain masyarakat senantiasa memepertanyakan manfaat koperasi dalam pembangunan ekonomi, khususnya dalam meningkatkan kesejahteraan para anggotanya (Yuyun Wirasasmita,2005).

Secara keseluruhan kondisi exiting koperasi di Kabupaten Karawang dapat dilihat dari hasil FGD (Focus Group Discussion) yang di hadiri oleh 7 Pengurus Koperasi di Kabupaten Karawang seperti dalam tabel dibawah ini : 
Tabel 1

Nama Koperasi Peserta FGD

\begin{tabular}{|c|c|c|c|c|}
\hline $\begin{array}{l}\text { Nama } \\
\text { Koperasi }\end{array}$ & $\begin{array}{c}\text { Status, Akta } \\
\text { Pendirian }\end{array}$ & Lokasi & Jenis Usaha & Kategori \\
\hline $\begin{array}{l}\text { KSU } \\
\text { Sinar Buana }\end{array}$ & $\begin{array}{l}\text { Berbadan Hukum } \\
\text { 57/BH/XIII.10/XI/20 } \\
11\end{array}$ & $\begin{array}{l}\text { Desa } \\
\text { Mekarbuana } \\
\text { Kec. } \\
\text { Tegalwaru }\end{array}$ & Serba usaha & $\begin{array}{c}\text { Aktif (Tidak ada laporan } \\
\text { RAT) }\end{array}$ \\
\hline $\begin{array}{l}\text { KUD } \\
\text { Warga Sari } \\
\text { Bhakti }\end{array}$ & $\begin{array}{l}\text { Berbadan Hukum } \\
5783 / \mathrm{BH} / \mathrm{PAD} / \mathrm{KWK} \\
.10 / \mathrm{VI} / 1996\end{array}$ & $\begin{array}{l}\text { Desa } \\
\text { Cintalaksana } \\
\text { kec. } \\
\text { Pangkalan }\end{array}$ & Serba usaha & $\begin{array}{c}\text { Aktif (Tidak ada laporan } \\
\text { RAT) }\end{array}$ \\
\hline $\begin{array}{l}\text { KOPWAN } \\
\text { Kemuning }\end{array}$ & $\begin{array}{l}\text { Berbadan Hukum } \\
\text { 13/BH/XIII.10/IV/20 } \\
12\end{array}$ & $\begin{array}{l}\text { Kec. Teluk } \\
\text { Jambe } \\
\text { Timur }\end{array}$ & Serba usaha & Aktif (ada laporan RAT \\
\hline $\begin{array}{l}\text { KUD } \\
\text { Mina } \\
\text { Sinarperbangsa }\end{array}$ & $\begin{array}{l}\text { Berbadan Hukum } \\
\text { 7088/BH/PAD/KWK } \\
.10 / \mathrm{IX} / 1995\end{array}$ & Ciparagejaya & Serba usaha & Aktif (ada laporan RAT) \\
\hline KKT Bagja & $\begin{array}{l}\text { Berbadan Hukum } \\
\text { 10/BH/KDK.10.9/1/I } \\
\text { X/1998 }\end{array}$ & $\begin{array}{l}\text { Desa } \\
\text { Sukatani } \\
\text { Kec. } \\
\text { Cilamaya } \\
\text { Wetan }\end{array}$ & $\begin{array}{l}\text { Koperasi } \\
\text { kelompok Tani }\end{array}$ & Aktif (ada laporan RAT) \\
\hline $\begin{array}{l}\text { Koperasi } \\
\text { Produsen } \\
\text { TUNAS } \\
\text { KARYA } \\
\end{array}$ & $\begin{array}{l}\text { Berbadan Hukum } \\
44 / \mathrm{BH} / \mathrm{XIII} .10 / \mathrm{X} / 20 \\
12\end{array}$ & $\begin{array}{l}\text { Desa } \\
\text { Banyusari }\end{array}$ & Serba usaha & Aktif (ada laporan RAT \\
\hline $\begin{array}{l}\text { KSP } \\
\text { Jaya Mandiri }\end{array}$ & $\begin{array}{l}\text { Berbadan Hukum } \\
\text { 14/BH/XIII.10/VI/20 } \\
10\end{array}$ & $\begin{array}{l}\text { Kel. } \\
\text { Karawang } \\
\text { Barat }\end{array}$ & Simpan Pinjam & Aktif (ada laporan RAT \\
\hline
\end{tabular}

Sumber : Dinas Koperasi dan UMKM Kab. Karawang

Hasil dari FGD (Focus Group Discussion) digambarkan dengan mengidentifikasikan faktor-faktor strategis koperasi yaitu kekuatan, kelemamahan, peluang dan ancaman ( Analisis SWOT ) yang tertera pada tabel dibawah :

Tabel 1.3

Faktor faktor dalam analisis SWOT

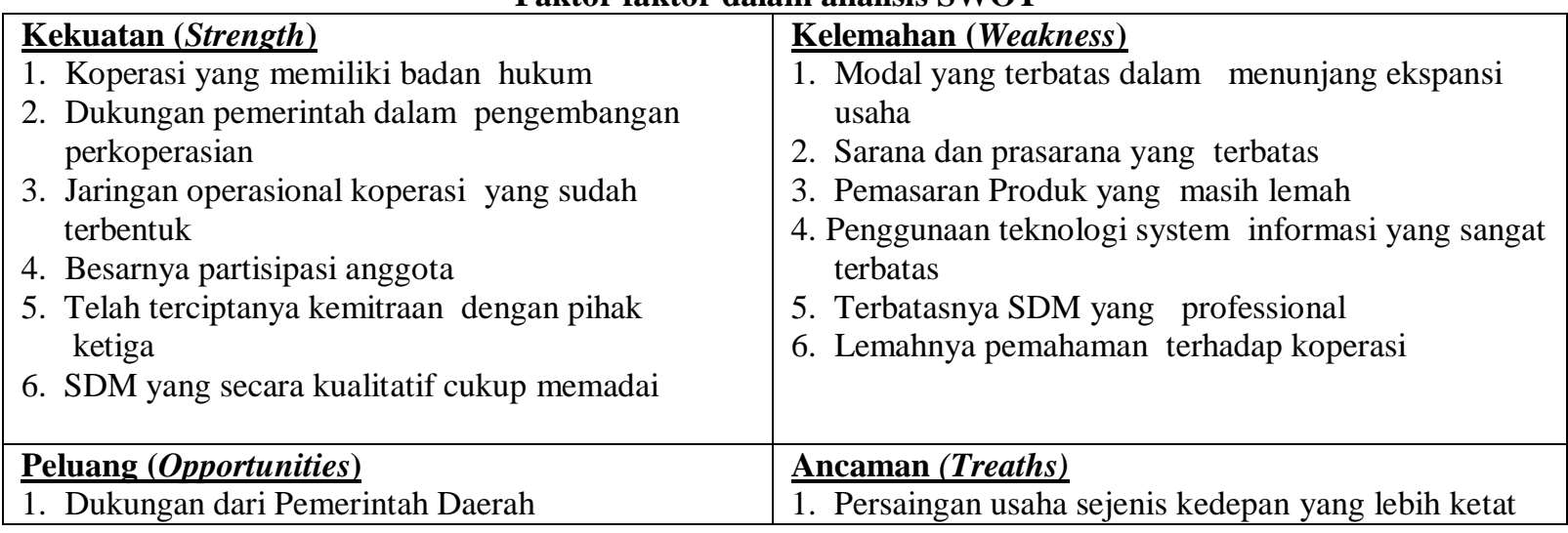


2. Pertumbuhan pendudukan yang cukup tinggi

3. Tingkat kesejahteraan masyarakat yang cukup baik

4. Besarnya potensi pasar

5. Meningkatnya kegiatan sector riil di kalangan pengusaha kecil dan menengah

6. Kemauan politik yang kuat dari pemerintah dan berkembangnya tuntunan masyarakat untuk lebih membangun koperasi

Sumber: Data primer pra penelitian, 2015.

Hasil dari identifikasi Faktor-faktor strategi dengan menggunakan analisis SWOT dibuatkan diagram matrik SWOT seperti dibawah ini :

\begin{tabular}{|c|c|c|}
\hline FAKTOR & Strength (S) & Weaknesses (W) \\
\hline Opportunities (O) & & $\begin{array}{l}\text { Melakukan interaksi dan } \\
\text { perbaikan antara kelemahan } \\
\text { organisasi dan peluang dari } \\
\text { luar untuk merubah strategi } \\
\text { dengan memanfaatkan peluang } \\
\text { yang ada }\end{array}$ \\
\hline Treaths $(T)$ & & \\
\hline
\end{tabular}

Diagram 1

Matrik SWOT, 2015

Posisioning matrik swot dari analisis faktor-faktor stategis diatas dapat dijadikan dasar untuk dilakukan penelitian terhadap kelompok koperasi non karyawan dengan melakukan interaksi dan perbaikan antara kelemahan organisasi dan peluang dari luar untuk merubah strategi dengan memanfaatkan peluang yang ada, yang berkaitan dengan kemampuan dayasaing.

\section{Fokus Penelitian}

Salah satu asumsi tentang gejala dalam pandangan penelitian kualitatif, bersifat holistik (menyeluruh, tidak dapat dipisah-pisahkan), artinya penelitian tidak hanya berdasarkan variabel tetapi keseluruhan situasi sosial yang diteliti dan meliputi aspek yaitu: tempat (place); pelaku (actor) dan aktivitas (activity) yang berinteraksi secara sinergis dalam mempertajam penelitan kualitatif, harus menetapkan fokus, dalam penelitian ini mempunyai fokus penelitian :

1. Tema tentang strategi pengembangan loperasi untuk dalam konsep dayasaing koperasi yang merupakan aktivitas (activity) dari organisasi koperasi.

2. Lokus penelitian ada pada kelompok koperasi non karyawan yang merupakan aspek tempat (place).

130. 
3. Adanya domain informan dari para pengrus, pengawas dari masing -masing koperasi serta ekspert (sumber ahli) yang merupakan aspek pelaku (actor).

\section{Tujuan Penelitian}

Penelitian ini bertujuan untuk :

1. Mengidentifikasi dan menganalisis penerapan manajemen strategi pada koperasi di Kabupaten Karawang;

2. Mengkaji konsep dayasaing yang diterapkan pada koperasi di Kabupaten Karawang ;

3. Mengidentifikasi dan menganalisis kendala-kendala yang dihadapi oleh koperasi dalam menghadapai dayasaing.

4. Mengkaji strategi pengembangan dalam upaya meningkatkan dayasaing koperasi.

\section{Kajian Teori}

Organisasi

Parson dalam Gudono (2012:4) mendefinisikan organisasi sebagai unit sosial yang dibentuk semata-mata untuk mencapai tujuan yang spesifik. Agar pencapaian tujuan bisa dilakukan secara efisien, kordinasi kegiatan membutuhkan struktur yang rasional dimana pihak yang diberi otoritas sebagai penguasa (untuk memberikan perintah-command) dan ada yang menjadi yang dikuasai (untuk menjalankan perintah).

Sebuah organisasi dapat terbentuk karena dipengaruhi oleh beberapa aspek seperti penyatuan visi dan misi serta tujuan yang sama dengan perwujudan eksistensi sekelompok orang tersebut terhadap masyarakat. Organisasi yang dianggap baik adalah organisasi yang dapat diakui keberadaannya oleh masyarakat disekitarnya, karena memberikan kontribusi seperti; pengambilan sumber daya manusia dalam masyarakat sebagai anggota-anggotanya sehingga menekan angka pengangguran (http://id.wikipedia.org/wiki/Organisasi).

\section{Organisasi Koperasi}

Menurut Tiktik Sartika (2009) secara pragmatis (=esesialis) organisasiorganisasi koperasi di definisikan" sebagai organisasi yang didirikan dengan tujuan utama menunjang kepentingan ekonomi para anggotanya melalui suatu perusahann bersama”.

Ditinjau dari pola struktural definisi tersebut ada 4 unsur yang menunjukkan ciri khusus koperasi sebagai bentuk organisasi :

1). Adanya sejumlah individu yang bersatu dalam suat kelompok yang memiliki sekurang-kurangnya satu kepentingan;

2). Angan-angan individual dari kelompok koperasi antara lain bertekad mewujudkan tujuannya untuk memperbaikai situasi ekonomi dan sosial mereka melalui usaha-usaha bersama dan saling membantu (swadaya dari kelompok koperasi)

3). Sebagai suatu instrumen (sarana) untuk mencapai tujuan itu, yaitu melalui pembentukan suatu perusahaan;

4). Adanya sasaran utama dari perusahaan koperasi itu, yaitu melaksanakan kegiatan-kegiatan yang menunjang/memperbaiki situasi ekonomi para anggota (memperbaiki situasi ekonomi perusahaan atau rumah tangga anggota). 


\section{Manajemen Strategik Koperasi}

Mengacu pendapat Peter Davis dalam Tati, 2005 Manajemen strategis koperasi (Cooperative Management Startegic) :

1. Strategis harus berjalan pada tingkat fungsional operasional, maupun tingkat koperasi sebagai badan usaha (corporate);

2. Tidak akan pernah ada program manjemen strategis koperasi yang efektif tanpa manajemen sumber daya manusia, sebab Manajemen strategis koperasi berpusat pada orang (human centred) dan dipengaruhi oleh nilai-nilai serta budaya organisasi;

3. Koperasi perlu melakukan merjer dan bukan bersaing di dalam pasar global, tetapi harus mampu bersaing dengan perusahaan "transnational"di dalam pasar nasional;

4. Identitas dan tujuan koperasi memerikan koperasi arah strategis dan legitimasi serta diferensiasi di dalam pasar, yaitu nilai-nilai koperasi strtegis yang besar;

5. Akar komunitas koperasi dan prinsip keanggotaan (membership based) adalah kekuatan strategis yang besar, yang memungkinkan koperasi mampu secara efektif mengembangkan "kompetensi" lokal untuk mengalahkan perusahaan transnational dalam persaingan;

6. Koperasi dapat mengembangkan suatu "global brand", berdasarkan identitas, nilai-nilai dan tujuan koperasi. Hal ini akan sangat memperkuat dayasaing tingkat nasioanl dari koperasi-koperasi primer;

7. Komite sektoral ICA (International Cooperative Alliances) harus diperkuat agar mampu mengembangkan tim proyak untuk sektor tersebut. Untuk mengidentifikasi dan mengembangkan bisnis baru, serta mendukung pengembangan strtegi koperasi, pada tingkat nasional, tetapi dari sudut pandang global;

8. Koperasi harus belajar untuk bekerjasama pada tingkat global, pada wilayah pemasaran "public image" dan kesadaran masyarakat terhadap gerakan koperasi serta mengembangkan "top quality management";

9. ICA harus diperkuat untuk mampu melakukan kontrak denganlembaga independen yang dapat mnyusun standar kualitas bagi koperasi. Semua koperasi primer maupaun sekunder harus diakreditasikan untuk memenuhi standart kualitas tersebut. Hal ini penting untuk melindungi pemasaran "branded product" global, dari kelemahan manajemen koperasi primer yang tidak mampu mencapai WCCQ (World Class Cooperative Quality).

Secara kelembagaan, strategi akan memperjelas visi atau misi kita. Pengakuan terhadap "Core Values" dan mengidentifikasikan siapa "stakeholder". Secara organisasi, strategi berari "direction, focus, understanding, comitment, coordination and adjustment to chenge, and development". (Tati, 2005)

\section{Dayasaing}

Dayasaing adalah suatu konsep yang umum digunakan di dalam ekonomi, yang biasanya menuju kepada komitmen terhadap persaingan pasar dalam kasus perusahaan-perusahaan dan keberhasilan dalam persaingan internasional dunia dan persaingan bebas, dayasaing telah menjadi satu dari konsep-konsep kunci 
bagi perusahaan-perusahaan, negara-negara, dan wilayah-wilayah untuk bisa berhasil dalam pertisipasinya di dalam globalisasi dan perdagangan bebas dunia (Markovics, dalam Tambunan, 2008), seperti yang dikatakan berikut ini on micro level the concept of competitiveness means the skill of posisition gain and selfmaintainment in the market competition among companies, each other's competitors and -in respect of macro economy-among national economies (Lengyel, 2005 dikutip Markovisc, dalam Tambunan, 2008)

Porter, dalam Nur 2012 mengatakan bahwa dayasaing suatu Negara didasarkan kepada dayasaing berbagai industri dan atau perusahaan yang ada. Artinya, semakin tinggi dayasaing industri dan perusahaan maka dayasaing Negara juga akan meningkat. Demikian juga sebaliknya. Dan logika ini juga dapat digunakan untuk menentukan dayasaing industri yaitu berdasarkan dayasaing perusahaan yang ada dalam industri tersebut. Sebuah industri dikatakan memiliki dayasaing yang tinggi, apabila perusahaan-perusahaan memiliki kemampuan untuk menghasilkan, memasarkan dan menjual produk dan jasa yang mereka hasilkan.

Kadocsa dalam Nur 2012 mengatakan "A few values, indicators, or characteristic features that can be quantified and accessible, or are not quantifiable or accessible at all, or are difficult to quantify or access, have to be identified at corporate level. Menurut Kadocsa, ada beberapa indicator untuk mengukur dayasaing, yaitu penerimaan, ekspor, laba, pangsa pasar, produktifitas, standar teknis, nilai perusahaan, good will, pencitraan, kepuasan konsumen, dan nilai produk dan jasa yang dihasilkan. Kadocsa (2006) juga menyatakan bahwa secara garis besar, faktor yang mempengaruhi dayasaing dibagi menjadi dua, yaitu faktor eksternal dan faktor internal.

\section{Metodologi Penelitian Unit Analisis}

Unit analisis dari penelitian ini adalah 7 koperasi yang ada di Kabupaten Karawang. Fokus penelitian tentang penerapan strategi pengembangan koperasi agar koperasi yang sudah dibentuk dapat berkelanjutan. Sasaran dari penelitian ini adalah para pengurus dan anggota pada koperasi yang tercantum pada AD /ART koperasi.

\section{Jenis dan Sumber Data}

Data adalah fakta, informasi atau keterangan yang merupakan dasar untuk dapat ditemukan pemecahan berbagai permasalahan yang menjadi objek penelitian. Dalam penelitian kualitatif tidak menggunakan istilah populasi, tetapi oleh Spradley dinamakan "social situation" atau situasi sosial yang terdiri dari aspek tempat (place), pelaku (actor), dan aktivitas (activity) yang berinteraksi secara sinergis. Situasi sosial tersebut dalam hal ini berada di Koperasi di Kabupaten Karawang. Situasi sosial tersebut dapat dinyatakan sebagai obyek penelitian yang ingin difahami secara mendalam. "apa yang terjadi" di dalamnya.

Menurut Lofland dan Lofland dalam Lexy Moleong (2007:157) bahwa sumber data utama dalam penelitian kualitatif adalah kata-kata dan tindakan, selebihnya adalah data tambahan seperti dokumen dan lain lain. Penelitian ini 
dilakukan pada Koperasi di Kabupaten Karawang. Jenis data yang digunakan yaitu dat primer dan dat sekunder.

Data Primer merupakan data yang diambil secara langsung, data primer yang diperoleh dari :

1. Focus Group Discussion (FGD) dengan peserta 7 para pengurus koperasi dengan berbagai jenis usaha;

FGD adalah teknik pengumpulan data yang umumnya dilakukan pada penelitian kualitatif. Teknik ini dimaksud untuk memperoleh data dari suatu kelompok berdasarkan hasil diskusi yang terpusat pada suatu permasalahn tertentu (Burhan Bungin, 2012:237)

2. Wawancara dengan para pengurus Koperasi

3. Wawancara dengan pihak pemerintah dalam hal ini Bidang Kelembagaan Koperasi pada Dinas Koperasi dan UMKM Kabupaten Karawang.

Data sekunder dalam penelitian ini diambil dari :

1. Data Statistik Kementerian Koperasi dan UMKM

2. Data dari Dinas Koperasi dan UMKM Kabupaten Karawang

\section{Hasil Penelitian}

Penerapan Manajemen Strategi Koperasi Non Karyawan Di Kabupaten Karawang

Penerapan manajemen strategi koperasi karyawan pada saat pembentukan Koperasi belum mempunyai visi dan misi, tetapi adanya keinginan untuk maju dan berkembang dengan menyusun visi dan misi agar jelas target yang akan dicapai koperasi. Bahwa ada penilaian terhadap faktor-faktor diluar koperasi yang dapat mempengaruhi kemajuan koperasi, image masyarakat terhadap koperasi artinya lingkungan masih menganggap kuno, pelatihan manajemen koperasi masih kurang, persaingan usaha dan tidak peraturan yang mengikutkan peran serta koperasi dalam usaha, pembinaan pemerintah terhadap koperasi masih belum dirasakan oleh koperasi, adanya persaingan dengan pihak swasta yang lebih profesional dalam menjalankan usahanya sedangkan koperasi masih sederhana dengan kemajuan tehnologi koperasi masih tertinggal. Dilihat dari wilayah daerah Kostim mempunyai potensi pertanian yang cukup besar ini merupakan peluang tetapi apabila faktor iklim dan cuacanya mendukung.

Terdapat penilaian terhadap faktor-faktor dari dalam koperasi yang dapat mempengaruhi kemajuan koperasi pengurus Koperasi masih lemah dalam memanage koperasi, belum bisa menggunakan teknologi komputer karena terbatasnya SDM yang professional tetapi dari pengalaman pengurus mengelola koperasi sudah cukup lama, untuk partisipasi dan keaktifan anggota koperasi cukup tinggi. Jumlah modal yang dimiliki koperasi masih sangat terbatas dilihat dari banyaknya pengajuan pinjaman dari anggota belum bisa terpenuhi semua, juga Koperasi belum memiliki prosedur simpan pinjam yang baik, tetapi dilihat dari lokasi KKT Bagja mempunyai lokasi yang strategis.

Koperasi merumuskan strateginya dalam peningkatan dayasaing dengan menjabarkan dan merumuskan pada Rencana Kerja Koperasi dan Rencana Anggaran Pendapatan dan Belanja Koperasi (RK/RAPBK) sesuai target yang akan dicapai dan pengesahanya pada saat Rapat Anggota Tahunan koperasi.

Koperasi menerapkan strateginya yang sudah dirumuskan dalam RK/RAPBK pada tahun berikutnya sesudah RAT. Koperasi telah melaksanakan 
monitoring atau pemantauan serta penyesuaian terhadap strategi pengembangan di Koperasi

\section{Konsep Dayasaing Koperasi Non Karyawan Di Kabupaten Karawang}

Konsep dayasaing koperasi non karyawan bahwa koperasi mengelola usahanya sebagai lembaga ekonomi yang mandiri, koperasi didirikan dengan modal awal dari modal simpanan anggota yaitu simpanan pokok,simpanan wajib dan simpanan sukarela, dan bantuan modal dari pengusaha obat-obatan pertanian berupa barang konsinyasi serta adanya semangat dari anggota untuk turut berpartisipasi dan menjalin kemitraan. Pelayanan yang diberikan oleh koperasi kepada anggota selaku pemilik dan pelanggan belum terlalu maksimal.

Kontribusi koperasi terhadap pencapaian tujuan pembangunan pemerintah,bisa membantu masyarakat yang menjadi anggota dan masyarakat disekitar koperasi dengan bantuan sosial dalam bentuk beasiswa, serta meningkatkan taraf hidup dan membantu masyarakat sekitar terutama anggota koperasi agar lebih mudah mendapatkan kebutuhan sarana produksi pertanian dan masyarakat sekitar dapat memanfaatkan koperasi dengan begitu meningkatnya taraf hidup serta terbukanya lapangan kerja

\section{Kendala Kendala Yang Dihadapi Oleh Koperasi Dalam Menghadapai Dayasaing Koperasi}

Kendala-kendala yang dihadapi oleh koperasi dalam menghadapai dayasaing koperasi tentang perkoperasian belum memahami seluruhnya (pendidikan perkoperasian), kurangnya tenaga ahli komputer, tehnologi untuk pertanian belum punya, masih kurang informasi dari pusat serta belum punya jaringan kerja antar koperasi yang ada. Sulit mencari kader kepengurusan karena masalah SDM, pendidikan dan pengetahuan mengenai perkoperasian masih kurang.

\section{Strategi Pengembangan Koperasi Dalam Upaya Meningkatkan Dayasaing Koperasi Non Karyawan Di Kabupaten Karawang}

Strategi pengembangan koperasi dalam upaya meningkatkan dayasaing dengan meningkat modal kerja, mengembangkan usaha baru, memberikan pelatihan manajemen bagi pengurus, dan memberikan pemahaman koperasi kepada anggota, mencari pengurus yang mempunyai integritas terhadap koperasi dan menjalin kerjasama dengan koperasi yang sudah maju dan pihak distributor. Menjalin kemitraan, mensinergiskan antara pengurus pengawas dan anggota, partisipasi aktif dari anggota agar setiap program yang dibuat dalam RK/RAPBK dapat didukung pelaksanaanya.

\section{Pembahasan Penelitian}

Penerapan Manajemen Strategi Koperasi Non Karyawan di Kabupaten Karawang

Koperasi Kelompok Tani (KKT) BAGJA bermula terbentuk sebagai usaha keluarga yang mayoritas petani, karena semakin banyaknya masyarakat petani bergabung dan banyak pelanggan serta konsumen dari luar yang memanfaatkan keberadaannya, serta adanya keinginan dari anggota untuk peningkatan taraf hidup masyarakat petani disekitar Desa Sukatani, oleh karena itu pada saat pembentukan belum mempunyai Visi, Misi dan tujuan yang jelas dan tertulis serta belum menerapkan manjemen strategik seperti penerapan standar organisasi dan manajemen koperasi. Visi adalah alasan filosofi keberadaan suatu lembaga atau 
organisasi yang berhubungan dengan gambaran tentang apa yang akan terjadi dan menjadi arah atau pegangan bagi lembaga dalam mewujudkan cita-cita yang selaras den berkesinambungan, strategi adalah tujuan jangka panjang dari suatu perusahaan, serta pendayagunaan dan alokasi semua sumber daya yang penting untuk mencapai tujian tersebut, Chandler dalam Rangkuti, (2006).

Penilaian terhadap faktor-faktor diluar koperasi KKT Bagja yang dapat mempengaruhi kemajuan koperasi adanya image masyarakat terhadap koperasi masih menganggap kuno, lembaga koperasi hanya sebagai tempat untuk meminjam uang tanpa harus ada jaminan dan membeli kebutuhan dengan cara kredit. Pembinaan pemerintah terhadap koperasi masih belum banyak dirasakan, Persaingan dengan pihak swasta yang lebih profesional dalam menjalankan usahanya dibandingkan dengan pengelolaan koperasi yang masih sederhana, dari sisi tehnologi koperasi masih tertinggal itu merupakan suatu kelemahan bagi koperasi . KKT Bagja terletak di wilayah Sukatani yang mempunyai potensi pertanian yang cukup besar ini merupakan peluang termasuk faktor iklim dan cuaca

Penilaian terhadap faktor-faktor dari dalam yang dapat mempengaruhi kemajuan koperasi adalah masih banyak pengurus Koperasi memanage koperasi masih sebatas kemampuan yang ada, penggunaan teknologi komputer belum banyak karena terbatasnya SDM yang professional itu merupakan suatu kelemahan koperasi tetapi dari pengalaman pengurus mengelola koperasi sudah cukup lama. Partisipasi dan keaktifan anggota koperasi KKT Bagja cukup tinggi. Permodalan yang dimiliki koperasi masih sangat terbatas dilihat dari banyaknya pengajuan pinjaman dari anggota belum bisa terpenuhi semua, serta belum memiliki prosedur simpan pinjam yang baik, tetapi dilihat dari lokasi KKT Bagja mempunyai lokasi yang strategis.

Strateginya yang sudah dirumuskan dalam Rencana Kerja Koperasi dan Rencana Anggaran Pendapatan dan Belanja Koperasi (RK/RAPBK) akan dilaksanakan pada tahun berikutnya. Pelaksanaan monitoring atau pemantauan serta penyesuaian terhadap strategi pengembangan di Koperasi sudah dilakukan tidak dalam bentuk evaluasi.

Menurut Peter Davis dalam Tati (2005) tujuan dari manajemen strategi koperasi adalah agar koperasi mampu menjaga kesesuaian antara identitasnya, dan tujuannya serta lingkungannya. Koperasi harus mengembangkan strategi untuk menjaga dan mengembangkan pangsa pasarnya dan mengembangkan kemampuan memasok sesuai dengan kebutuhan anggota dan pelangganya secara menyeluruh.Strategi pada akhirnya berarti pencapaian keuntungan kompetitif di pasar. Penerapan Manajemen strategi pada koperasi non karyawan di Kabupaten Karawang belum optimal.

\section{Konsep dayasaing koperasi Non Karyawan di Kabupaten Karawang}

Permodalan koperasi merupakan satu indikator bahwa koperasi mengelola usahanya sebagai lembaga ekonomi yang mandiri, KKT Bagja sebagai lembaga ekonomi yang meandiri mempunyai modal awal dari modal simpanan anggota yaitu simpanan pokok,simpanan wajib dan simpanan sukarela. Selama ini bantuan modal dari pihak ketiga belum maksimal dan belum termanfaatkan oleh para anggota seluruhnya. Ada bantuan modal dari pengusaha obat-obatan pertanian berupa barang konsinyasi. Adanya semangat dari anggota untuk turut berpartisipasi. KKT Bagja berusaha untuk menjalin kemitraan baik dengan koperasi yang lebih maju maupun pihak lembaga keuangan lainnya. Pelayanan 
yang diberikan oleh koperasi kepada anggota selaku pemilik dan pelanggan belum terlalu maksimal

Kontribusi koperasi terhadap pencapaian tujuan pembangunan pemerintah,bisa membantu masyarakat yang menjadi anggota dan masyarakat disekitar koperasi dengan bantuan sosial dalam bentuk beasiswa, serta meningkatkan taraf hidup dan membantu masyarakat sekitar terutama anggota koperasi agar lebih mudah mendapatkan kebutuhan sarana produksi pertanian dan masyarakat sekitar dapat memanfaatkan koperasi dengan begitu meningkatnya taraf hidup serta terbukanya lapangan kerja

Dayasaing adalah sebuah konsep yang membandingkan kemampuan dan kinerja suatu perusahaan, sub sector atau Negara untuk menjual dan mensuplai barang dan jasa ke pasar yang dituju. (Easterly and Levine 2002) (sumber http://en.wikipedia.org/wiki/Competitiveness).. Semakin baik perbandingan antara ability dan performance menunjukkan bahwa perusahaan tersebut memiliki dayasaing yang kuat atau keunggulan bersaing. Namun demikian, dayasaing perusahaan tidak hanya ditentukan oleh kekuatan internal, tetapi juga sangat ditentukan oleh hubungan dengan pihak eksternal seperti pemasok, konsumen, pemerintah, dan bahkan dengan pesaing yang membantu mereka untuk mendapatkan keunggulan bersaing. Jaringan hubungan internal dan eksternal perusahaan ini oleh Kay ( 1993 : 66) disebut sebagai Architecture, yaitu a network of relational contract with or around the firm. Konsep dayasaing pada koperasi non Karyawan di Kabupaten Karawang belum diterapkan

\section{Kendala-kendala yang dihadapi koperasi dalam menghadapai dayasaing}

Sumber daya manusia terutama pengurus koperasi yang menjalankan aktivitas serta perputaran keuangan pada koperasi.Pengurus belum memahami tentang manajemen perkoperasian seluruhnya (pendidikan perkoperasian), kurangnya tenaga ahli komputer, tehnologi untuk pertanian masih belum dimiliki, masih kurang informasi dari pusat serta belum punya jaringan kerja antar koperasi yang ada. Sulit mencari kader kepengurusan karena masalah SDM, pendidikan dan pengetahuan mengenai perkoperasian masih kurang.

Menurut Kadocsa, ada beberapa indicator untuk mengukur dayasaing, yaitu penerimaan, ekspor, laba, pangsa pasar, produktifitas, standar teknis, nilai perusahaan, good will, pencitraan, kepuasan konsumen, dan nilai produk dan jasa yang dihasilkan. Kadocsa (2006) juga menyatakan bahwa secara garis besar, faktor yang mempengaruhi dayasaing dibagi menjadi dua, yaitu faktor eksternal dan faktor internal.

Kendala-kendala yang dihadapi oleh koperasi dalam menghadapi dayasaing koperasi berimplikasi menghambat pada kemampuan dayasaing koperasi di kabupaten Karawang.

\section{Strategi pengembangan koperasi dalam upaya meningkatkan dayasaing Koperasi}

Strategi penegmbangan yang dijalankan oleh KKT Bagja baru berupa meningkatkan simpanan anggota sedangkan peningkatan manajemen sumber daya manusianya dan manajemen perkoperasian belum banyak diterapkan hanya sebatas dari Rencana Anggaran Pendapatan Belanja Koperasi yang sudah disetujui pada Rapat Anggota Tahunan. Dengan meningkat modal kerja, 
mengembangkan usaha baru, memberikan pelatihan manajemen bagi pengurus baru akan dilaksanakan, dan memberikan pemahaman koperasi kepada anggota, mencari pengurus yang mempunyai integritas terhadap koperasi dan menjalin kerjasama dengan koperasi yang sudah maju dan pihak distributor. Menjalin kemitraan, mensinergiskan antara pengurus pengawas dan anggota, partisipasi aktif dari anggota agar setiap program yang dibuat dalam RK/RAPBK dapat didukung pelaksanaanya. Dana-dana penyisihan harus digunakan sesuai peruntuknya atau investasinya semuanya baru dalam rencana yang akan diterapkan.

Koperasi perlu mengembangkan strategi agar dapat memepertahankan fokus dan tujuan, agar dapat menegakkan dan mengembangkan nilai-nilainya, mengembangkan pelayanan bagi anggota dan pelanggannya. Strategi pengembangan koperasi dalam upaya peningkatan dayasaing memerlukan pengembangan dan membutuhkan perhatian dari berbagai pihak

\section{Kesimpulan}

Hasil penelitian strategi pengembangan koperasi dalam upaya peningkatan dayasaing di Kabupaten Karawang diperoleh kesimpulan :

1. Koperasi non karyawan di Kabupaten Karawang yang sudah dibentuk Penerapan Manajemen strategi masih belum optimal, seperti penerapan standar organisasi dilihat dari organisasi tersebut belum mempunyai Visi, Misi dan tujuan yang jelas dan tertulis.

2. Konsep dayasaing koperasi non Karyawan di Kabupaten Karawang sebagai lembaga ekonomi yang mandiri, belum diterapkan. Koperasi baru sebatas mengandalkan dari internal koperasi itu sendiri sedangkan konsep dayasaing juga ditentukan oleh hubungan dengan pihak eksternal seperti pemasok, konsumen, pemerintah, dan bahkan dengan pesaing yang membantu mereka untuk mendapatkan keunggulan bersaing.

3. Kendala-kendala yang dihadapi oleh koperasi dalam menghadapi dayasaing koperasi berimplikasi menghambat pada kemampuan dayasaing koperasi di kabupaten Karawang terutama Sumber Daya Manusia yang merupakan resources utama sebagai penggerak koperasi dan Manajemen strategis koperasi berpusat pada orang (human centred)

4. Strategi pengembangan koperasi dalam upaya peningkatan dayasaing memerlukan pengembangan dan membutuhkan perhatian dari berbagai pihak

\section{Rekomendasi}

Koperasi sebagai lembaga keuangan yang profesional, mandiri dan melayani anggota berdasarkan prinsip-prinsip koperasi seyogyanya bersedia mengkonsolidasi kegiatannya serta mengkaji ulang pola kerja dan organisasinya bagi meningkatkan kualitasnya, dengan penerapan strategi pengembangan Koperasi dalam upaya peningkatan dayasaing.

1. Koperasi yang sudah dibentuk sebaiknya menerapkan manjemen strategik yaitu dengan menerapkan standar organisasi dan manajemen dilihat dari organisasi tersebut mempunyai Visi, Misi dan tujuan yang jelas dan tertulis.
a. Membuat Visi
b. Menyusun Misi 
c. Tujuan Pendirian

d. Dinas Koperasi dan UMKM Kabupaten Karawang sebagai lembaga pembina koperasi di Kabupaten Karawang, mensinergikan programprogram pembangunan dengan pemberdayaan koperasi.

2. Konsep dayasaing koperasi non karyawan di Kabupaten Karawang bisa dilakukan mulai dari :

a. Pemahaman anggota yang akan bergabung dalam koperasi.

b. Berperan aktif dalam melakukan pengawasan terhadap jalannya usaha koperasi.

c. Jika anggota sebagai pengguna jasa meliputi:

Memanfaatkan jasa pelayanan koperasi

d. Melakukan Analisa SWOT untuk koperasi

e. Dinas Koperasi dan UMKM Kabupaten Karawang sebagai lembaga pembina koperasi di Kabupaten Karawang memberikan bantuan manajemen kepada koperasi baik pengurus ataupun sebagai manajer melalui pelatihan-pelatihan yang berkesinambungan.

3. Kendala-kendala yang dihadapi koperasi non karyawan dalam menghadapai dayasaing seperti :

a. Sumber daya manusia salah satu kendala yang dihadapi koperasi untuk mencari kaderisasi pengurus disikapi dengan mencari pengurus dengan berlatar pendidikan minimal SLTA yang nantinya di ikutkan pelatihan manajemen tentang koperasi dengan mengoptimalkan dana-dana penyisihan sesuai dengan investasinya.

b. Kendala permodalan bagi koperasi dilihat dari laporan keuangan koperasi, dalam laporan keuangan koperasi Pengurus harus memuat:

1) Neraca

2) Perhitungan Hasil Usaha

3) Laporan perubahan ekuitas (modal)

4) Laporan Arus Kas

c. Dinas Koperasi dan UMKM Kabupaten Karawang sebagai lembaga pembina koperasi di Kabupaten Karawang mengeluarkan kebijakan guna mendorong percepatan pemberdayaan koperasi secara terarah dan bertahap. Kebijakan tersebut meliputi aspek-aspek kelembagaan, permodalan, kemampuan teknologi, kualitas SDM, pemasaran, jaringan usaha, menciptakan iklim yang kondusif, dan bertahap dimulai skema hibah untuk peningkatan keterampilan usaha, dana bergulir, pinjaman lunak, modal ventura dan pinjaman lunak. Secara terarah program ini dapat menyentuh segala aspek yang bertujuan dalam jangka pendek maupun dalam jangka panjang, memberikan bantuan modal kerja bagi koperasi, dimana bantuan tersebut harus selektif, dimonitoring dan evaluasi.

4. Strategi pengembangan koperasi dalam upaya meningkatkan dayasaing koperasi dengan :

a. Menerapkan enam tahapan dalam proses perencanaan strategis
1) Definisikan misi
2) Analisis lingkungan
3) Analisis organisasi
4) Merumuskan strategi 
5) Melaksanakan strategi

6) Memantau dan menyesuaikan

b. Meningkatkan simpanan anggotanya, bekerja sama atau menjalin kemitraan dengan koperasi yang sudah maju.

c. Dinas Koperasi dan UMKM Kabupaten Karawang sebagai lembaga pembina koperasi di Kabupaten Karawang, memberikan peranan yang lebih besar pada koperasi dalam pengembangan koperasi, penambahan modal, pelatihan manajemen, dan bantuan perizinan agar koperasi memiliki posisi tawar lebih baik.

\section{Daftar Pustaka}

\section{Buku dan Jurnal}

Ahmad Sidik Omar, 2010. Faktor-faktor yang mempengaruhi perkembangan koperasi kredit hubungan jumlah anggota dan pertisipasi ekonominya terhadap total asset suatu koperasi kredit. Tesis. Universitas Terbuka. http://www.pustaka.ut.ac.id/dev25/index.php?option=com_content\&view=article\&id=1166 :faktor-faktor-yang-mempengaruhi-perkembangan-koperasi-kredit-hubungan-jumlahanggota-dan-partisipasi-ekonomi-terhadap-total-asset-suatu-koperasikredit\&catid $=21 \&$ Itemid $=412$

Alfred Hanel, 2005. Organisasi Koperasi, Graha Ilmu, Jogjakarta

Anwar Prabu Mangkunegara, 2009. Manajemen Sumber Daya Manusia Perusahaan, Remaja Rosdakarya, Bandung. p.2

Ardhuan Yuananda, 2013. Strategi Pengembangan Koperasi Samitra Kecamatan Semarang Selatan Kota Semarang. Jurnal. Universitas Negeri Semarang. http://journal.unnes.ac.id/sju/index.php/edaj

Asted Duriani Poeringtyas, 2010. Strategi Pengembangan Koperasi Setia Budi Wanita Dengan Pendekatan Analisis Swot. Tesis. STIE Malangkucecwara. Malang.

http://osrel.stie-mce.ac.id/?page=thesis\&level=s1\&id=7515

Burhan Bungin, 2008. Penelitian Kualitatif, Kencana Prenada Media Group, Jakarta

David, Fred R, 2012. Manajemen Strategis, Salemba Empat, Jakarta, p. 17,p.18.p.20,p.21,p. 229.

Farah Bonita, 2013. Strategi Pengembangan Industri Kecil Kerajinan Batik Di Kota Semarang. Jurnal. Universitas Negeri Semarang. http://journal.unnes.ac.id/sju/index.php/edaj.

Freddy Rangkuti, 2006. Analisis SWOT: teknik membedah kasus bisnis, Gramedia Pustaka Utama, Jakarta.

Hill, Mc Graw, 2011. Manajemen Sumber Daya Manusia Mencapai Keunggulan Bersaing, Salemba Empat, Jakarta,p.95

Iman Suhartono, 2011. Strategi Pengembangan Koperasi Berorientasi Bisnis. Jurnal. STIE AMA Salatiga.

Jochen Ropke, 2012. Ekonomi Koperasi, Graha Ilmu, Yogyakarta

Lexy Moleong, 2007. Metodologi Penelitian Kualitatif, Edisi Revisi, Remaja Rosdakarya, Bandung

Panji Anoraga, 2009. Manajemen Sumber Daya Manusia Bisnis, Rineka Cipta, Jakarta, p. 109

Soetrisno,Noer 2003. .Ekonomi Rakyat-Usaha Mikro dan UKM dalam Perekonomian Indonesia: Suatu Pandangan Struktural 
Alternatif.(www.smecda.com/.. $\%$ 20Usaha\%20Mikro\%20dan\%20UKM.Pdf)

./Ekonomi\%20Rakyat\%20-

Sondang P. Siagian, 2012. Manajemen Sumber Daya Manusia, Bumi Aksara, Jakarta. p. 27

Sugiyono, 2011. Metode Penelitian Kuantitatif , Kualitatif, dan R\&D, Alfabeta, Bandung

Susilawetty dan Karna Supena,2013. Peran Koperasi Serba Usaha Mutiara Mandiri Untuk Meningkatkan Perekonomian Masyarakat Gunung Sindur Kabupaten Bogor. Jurnal. Universitas Muhammadiyah Jakarta. ISSN 23383321

Tati Suhartati Joesron, 2005. Manajemen Strategik Koperasi, Graha Ilmu, Yogyakarta.

Tiktik Sartika Partomo, 2009. Ekonomi Koperasi, Ghalia Indonesia, Bogor

Urip Triyono, 2003. Pengembangan Koperasi Desa Pantai untuk Menunjang Pembangunan Wilayah Pesisir secara Berkelanjutan (Studi Kasus Koperasi Tambak di Kabupaten Indraamayu).Disertasi. Program Doktor. Program Pascasarjana Institut Pertanian Bogor. Bogor

Veithzal R dan Sagala.E.J, 2011. Manajemen Sumber Daya Manusia untuk Perusahaan, Rajawali Press. Rajagrafindo Persada Jakarta. p16, p.28

Wheelen, Thomas L. and Hunger, J David, 2003 Manajemen Strategis, Andi, Yogjakarta, p4

http://www.researchgate.net/profile/Nur_Efendi/publication/235766698_Analysis _of_Indonesia_Textile_Industry_Competitiveness_in_Regulation_Theory_P erspective_By_Nur_Efendi/file/79e4151359bb8d2c95.pdf

http://www.kadin-indonesia.or.id/enm/images/dokumen/KADIN-98-30001072008.pdf

\section{Peraturan, Kebijakan dan Buku Pedoman}

Laporan Interim Penyusunan Grand Design Pembangunan Koperasi Kabupaten Karawang Tahun 2013

Rencana Strategis Dinas Koperasi dan Usaha Mikro Kecil dan Menengah Tahun 2010-2014

Undang Undang Dasar Negara Republik Indonesia Tahun 1945

Undang-Undang Nomor 25 Tahun 1992 tentang Perkoperasian

Laporan RAT KKT “Bagja” Tahun 2010-2014 